\title{
SIMULTANEOUS DETERMINATION OF FIVE PHTHALATES IN WHITE SPIRITS USING LIQUID-LIQUID EXTRACTION FOLLOWED BY GAS CHROMATOGRAPHY-MASS SPECTROMETRY
}

\section{Danica S. Bogdanović1, Tatjana D. Anđelković1, Ivana S. Kostić1, Gordana M. Kocić2}

${ }_{1}^{1}$ University of Niš, Faculty of Science and Mathematics, Department of Chemistry, Niš, Serbia

2University of Niš, Faculty of Medicine, Niš, Serbia

The aim of this paper is the development of the method for determination of five phthalates in white spirits. Dimethyl phthalate (DMP), di-n-butyl phthalate (DBP), benzyl butyl phthalate (BBP), di-(2-ethylhexyl) phthalate (DEHP) and di- $n$-octyl phthalate (DOP) were extracted from white spirits by the optimized liquid-liquid extraction (LLE) method. In order to determine the best method for phthalate determination, LLE procedure was optimized by changing the following parameters: the number of extraction repetitions (1-4), the partial removal of ethanol by evaporation from alcoholic samples prior extraction, the type of agitation and the extraction time. Quantification was achieved by gas chromatography-mass spectrometry (GC-MS) with di- $n$-butyl adipate (DBA) as internal standard. Phthalates were analyzed using a single ion monitoring (SIM) mode and a base ion for each phthalate was chosen ( $m / z 149$ for DBP, BBP, DEHP and DOP and $m / z 163$ for DMP). The results show that the most effective phthalate extraction with $n$-hexane as a solvent is achieved with agitation by hand shaking with one-step extraction. Evaporation of ethanol from alcohol drinks provided the increased recovery value for DMP extraction but did not have an impact on the recovery values of DBP, BBP, DEHP and DOP extractions from the samples..
(ORIGINAL SCIENTIFIC PAPER) UDC 547.584:663.241:66.061:543.42

Keywords: phthalates, white spirit, extraction procedure, GC-MS analysis

\section{Introduction}

Phthalates are phthalic acid esters with two esters group in ortho position. The difference between phthalates comes from different alcohols that form the phthalic acid esters in the esterification reaction. These chemical organic compounds have high density, low solubility in water, but high solubility in organic solvents. The physicochemical properties of common phthalates present in alcoholic beverages are given in Table 1 [1].

Table 1. Physicochemical properties of common phthalates present in alcoholic beverages

\begin{tabular}{ccccccc}
\hline $\begin{array}{c}\text { Phthalate } \\
\text { compound }\end{array}$ & $\begin{array}{c}\text { Chemical } \\
\text { formula }\end{array}$ & $\begin{array}{c}\text { Molecular } \\
\text { mass } \\
\left(\mathrm{g} \mathrm{mol}^{-1}\right)\end{array}$ & $\begin{array}{c}\text { Boiling } \\
\text { point }\left({ }^{\circ} \mathrm{C}\right)\end{array}$ & $\begin{array}{c}\text { Density } \\
\left(\mathrm{g} \mathrm{cm}^{-3}\right)\end{array}$ & $\begin{array}{c}\text { Solubility in } \\
\text { water at } 25^{\circ} \mathrm{C} \\
\left(\mathrm{mg} \mathrm{L}^{-1}\right)\end{array}$ & Log Kow \\
\hline DMP & $\mathrm{C}_{10} \mathrm{H}_{10} \mathrm{O}_{4}$ & 194.18 & 282 & 1.19 & 5220 & 1.61 \\
DBP & $\mathrm{C}_{16} \mathrm{H}_{22} \mathrm{O}_{4}$ & 278.35 & 340 & 1.05 & 9.9 & 4.27 \\
BBP & $\mathrm{C}_{19} \mathrm{H}_{20} \mathrm{O}_{4}$ & 312.37 & 370 & 1.10 & 3.8 & 4.70 \\
DEHP & $\mathrm{C}_{24} \mathrm{H}_{38} \mathrm{O}_{4}$ & 390.56 & 385 & 0.99 & $2.49 \times 10^{-3}$ & 7.73 \\
DOP & $\mathrm{C}_{24} \mathrm{H}_{38} \mathrm{O}_{4}$ & 390.56 & 385 & 0.98 & $2.49 \times 10^{-3}$ & 7.73 \\
\hline \multicolumn{7}{l}{ Kow - octanol-water partition coefficient }
\end{tabular}

Phthalates are commonly used as plasticizers, which gives them widespread usage: in the industry of care products, children's toys, beverage industry, in the production of various packaging. The most commonly used phthalates are dimethyl phthalate (DMP), di-n-butyl phthalate (DBP), benzyl butyl phthalate (BBP), di-(2-ethylhexyl) phthalate
(DEHP) and di- $n$-octyl phthalate (DOP).

Alcoholic beverages are divided in three groups: spirits, beers and wines. Spirits are distilled beverages containing ethanol, and these include the following drinks: vodka, brandy, gin, tequila, rum, whisky, etc. During the production process of alcoholic beverages, alcohol can contact poten-

\footnotetext{
*Author address: Danica Bogdanović, University of Niš, Faculty of Science and Mathematics,

Department of Chemistry, Višegradska 33, 18000 Niš, Serbia

E-mail: dannica.milojkovic@gmail.com

The manuscript received: May, 28, 2019.

Paper accepted: June, 10, 2019.
} 
tial phthalate sources such as polyvinyl chloride (PVC) materials in different production phases and plastic packaging of alcoholic drinks. Plastic bottles for alcoholic drinks are an important phthalate contamination source since ethanol provides solubility of phthalates and thus a leaching effect of phthalates from packaging material into the alcohol beverage should not be neglected. Since phthalates are not bound by a covalent bond for plastics, they are only incorporated in plastics and they easily migrate from plastic material to the environment. In this way, phthalates pollute alcoholic beverages when these compounds are being leached into. The interest in monitoring phthalate concentrations in alcoholic beverages is high because alcoholic beverages are the product consumed by the adult population, and therefore there is a health risk if they consume an unrecorded alcohol that contains a high dose of phthalates. Researches have shown that phthalates are harmful to human health [2-5], and a maximum allowable dose level (MADL) for the DBP and DEHP in alcoholic drinks is 0.7 $\mathrm{mg} \mathrm{kg}^{-1}\left(0.7 \mu \mathrm{g} \mathrm{mL}^{-1}\right)$ by direction of the European Union [6]. Special attention is given to DEHP since it comprises a quarter of all produced plasticizers and shows a great environmental impact. Its high hydrophobicity (log Kow=7.73) makes it highly persistent and bioaccumulating.

The determination of the phthalates concentration in white spirits consists of phthalates extraction with $n$-hexane, chromatographic separation on a capillary column, the identification of the retention time and mass spectrum, and the quantification with characteristic ions $\mathrm{m} / \mathrm{z}$. The crucial point in the phthalate determination in white spirit is to develop a method for the extraction of phthalates. The aim of this research is to optimize the sample preparation procedure with the ethanol removal, the type of agitation during extraction and the extraction time. $n$-Hexane was chosen as good extractant, as noted in previous research [7]. In order to obtain a better recovery of phthalates, two types of agitation (ultrasound and vigorous handshake) are tested to see the optimal method. It was also examined how the extraction time, the number of extraction repetitions (1-4) and the ethanol removal affect the obtaining of the best recovery.

\section{Experimental}

\section{Chemicals and reagents}

The $n$-hexane (HPLC grade) was purchased from Carlo Erba (France). Dimethyl phthalate (DMP), di- $n$-butyl phthalate (DBP), benzyl butyl phthalate (BBP), di-(2-ethylhexyl) phthalate (DEHP) and di-n-octyl phthalate (DOP) were all of GC grade and were purchased from Sigma-Aldrich (USA). The di-n-butyl adipate (DBA) was also GC grade and was purchased from Sigma-Aldrich (USA).

A stock standard solution of the five investigated phthalates was prepared at the concentration of $1000 \mathrm{~g} \mathrm{~mL}^{-1}$ of each phthalate in $n$-hexane. From this solution, a standard solution was prepared at the concentration of $100 \mu \mathrm{g}$ $\mathrm{mL}^{-1}$ of each phthalate in $n$-hexane. Calibration solutions of phthalates at concentrations of $0.25,0.5,1.0,1.5,2.5$,
5.0, 7.5 and $10.0 \mu \mathrm{gL} \mathrm{m}^{-1}$ were prepared by diluting the standard solution in $n$-hexane. The DBA was used as the internal standard. The concentration of the internal standard in each calibration dilution was $1 \mu \mathrm{g} \mathrm{mL}^{-1}$.

\section{GC-MS technique}

Gas chromatographic analysis was performed on a gas chromatograph 6890 (Hewlett-Packard) equipped with a mass selective detector (MSD) 5973 (Agilent) and a DB-5 MS capillary column $(30 \mathrm{~m} \times 250 \mathrm{~mm} \times 0.25 \mathrm{~mm})$. The mass spectra were recorded under an electron impact ionization voltage of $70 \mathrm{eV}$. The gas chromatograph was operated in the split less injection mode. The oven temperature was programmed from $60{ }^{\circ} \mathrm{C}(1 \mathrm{~min})$ to $220{ }^{\circ} \mathrm{C}(1 \mathrm{~min})$ at the rate of $20^{\circ} \mathrm{C} \mathrm{min}-1$ and then to $280{ }^{\circ} \mathrm{C}(4 \mathrm{~min})$ at the rate of $5{ }^{\circ} \mathrm{C} \mathrm{min}^{-1}$. The MSD was used in the single ion-monitoring mode (SIM). The identification and quantification of target compounds was based on the relative retention time, the presence of target ions and their relative abundance. For quantification, peak area ratios of the analytes to the internal standard DBA were calculated as a function of the concentration of substances.

\section{Glassware and Reagent Control}

In order to minimize phthalate contamination from the laboratory, only glassware was used, rinsed with acetone and $\mathrm{n}$-hexane and dried at $200{ }^{\circ} \mathrm{C}$ in the oven for 4 hours [9]. n-Hexane was checked for potential phthalate contamination by GC-MS analysis once a week.

\section{Sample preparation}

The samples used for this investigation were apple brandy and vodka. Those two samples contain $46 \%$ and $40 \%(\mathrm{v} / \mathrm{v})$ ethanol, respectively. The samples $(10 \mathrm{~mL})$ were spiked with $25 \mu \mathrm{g}$ of each investigated phthalate. After that, the ultrasonic bath was used in order to completely dissolve the phthalates in the samples of alcoholic drinks. Since phthalates are highly dissoluble in ethanol, the extraction of phthalates using n-hexane could be less effective. In order to test the effect of ethanol on the phthalate recovery, the evaporation of alcohol samples was carried out to decrease the ethanol content. In this way, non-evaporated and evaporated samples were investigated. The sample volume of $10 \mathrm{~mL}$ was transferred into a glass tube and then heated in a boiling water bath to decrease the ethanol content. The tube was removed from the water bath with a residual volume of about $5 \mathrm{~mL}$ of alcoholic drinks. The contamination of the samples was monitored by blank samples which were treated the same way as other samples.

\section{Extraction procedures}

The liquid-liquid extraction procedure was performed after cooling heated samples. $n$-hexane $(5 \mathrm{~mL})$ was added to spiked alcoholic non-evaporated samples $(10 \mathrm{~mL})$ and evaporated samples $(5 \mathrm{~mL})$ and after that, agitation was carried out in two proposed ways. One way was vigorous hand shaking for $5 \mathrm{~min}$ and the second way was ultrasound agitation for $10 \mathrm{~min}, 20 \mathrm{~min}$ and $30 \mathrm{~min}$. In this way, the 
influence of the evaporation of ethanol from alcoholic samples, the influence of agitation (ultrasound or handshake) and the influence of the extraction time were tested.

Also, the repetition of liquid-liquid extraction was carried out (the number of extraction repetitions up to four) and for this test, the samples of vodka were used. The method of the sample preparation was the same as in the case of the apple white spirit, with the following steps: spiking, evap- oration and the addition of $n$-hexane. After removing the n-hexane layer, a new volume of $n$-hexane was added to alcohol and re-extractions were carried out. After separating the organic layer, the bottom layers of organic solvents were drained through a paper filter with the anhydrous sodium sulfate layer. The $n$-hexane extracts were transferred into a gas chromatography vial and analyzed using GC-MS.

Table 2. Retention times, quantification ions and identification ions of the phthalates and DBA

\begin{tabular}{lcccccc}
\hline & $\begin{array}{c}\text { Retention } \\
\text { time }(\mathrm{min})\end{array}$ & $\begin{array}{c}\text { Quantification } \\
\text { lons }(\mathrm{m} / \mathrm{z})\end{array}$ & $\begin{array}{c}\text { Identification } \\
\text { ions }(\mathrm{m} / \mathrm{z})\end{array}$ & $\begin{array}{c}\mathrm{LOD} \\
\left(\mu \mathrm{g} \mathrm{mL}^{-1}\right)\end{array}$ & $\begin{array}{c}\mathrm{LOQ} \\
\left(\mu \mathrm{g} \mathrm{m}^{-1}\right)\end{array}$ & $\mathrm{R}^{2}$ \\
\hline DMP & 7.906 & 163 & 164 & 0.05 & 0.15 & 0.999 \\
DBP & 11.406 & 149 & 150,223 & 0.02 & 0.06 & 0.998 \\
BBP & 15.700 & 149 & 91,206 & 0.03 & 0.10 & 0.998 \\
DEHP & 18.047 & 149 & 176,279 & 0.05 & 0.15 & 0.995 \\
DOP & 20.671 & 149 & 150,279 & 0.03 & 0.10 & 0.996 \\
DBA & 9.839 & 185 & 259 & $/$ & $/$ & $/$ \\
\hline
\end{tabular}

\section{Results and discusion}

\section{GC-MS acquisition}

All the phthalates were separated using the designated chromatographic conditions. The chromatogram of the phthalates standard solution in the concentration of 2.5 $\mu \mathrm{g} \mathrm{mL} \mathrm{m}^{-1}$ is given in Fig. 1. Linearity was investigated in the phthalate concentration range $0.1-10.0 \mu \mathrm{g} \mathrm{mL}^{-1}$. The calibration curves of all phthalates for the range of 0.25 to 2.5 $\mu \mathrm{g} \mathrm{mL}-1$ were linear with a correlation coefficient $\left(R^{2}\right)$ from 0.995 to 0.999 . The calibration curve obtained for DEHP in the concentration range $0.25-2.5 \mu \mathrm{g} \mathrm{mL}^{-1}$ was linear and it is given in Fig. 2. The retention times, selected ions for the analysis of the target phthalates and the DBA, the limit of detection (LOD) and the limit of quantitation (LOQ) for each phthalate are shown in Table 2. LOD and LOQ for each phthalate were calculated from six replicated measurements of low concentration standard solutions according to the literature data. LOD and LOQ were calculated from the signal/noise ratios which were multiplied with factor 3 and 10 respectively [8].

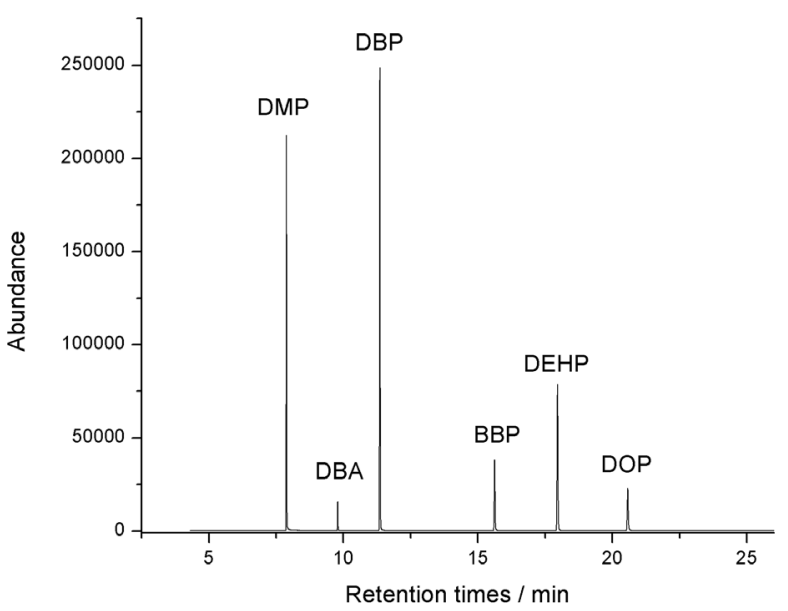

Figure 1. The chromatogram of investigated phthalates in the concentration of $2.5 \mu \mathrm{g} \mathrm{mL}^{-1}$ and DBA in the concentration of $1 \mathrm{\mu g} \mathrm{mL}^{-1}$

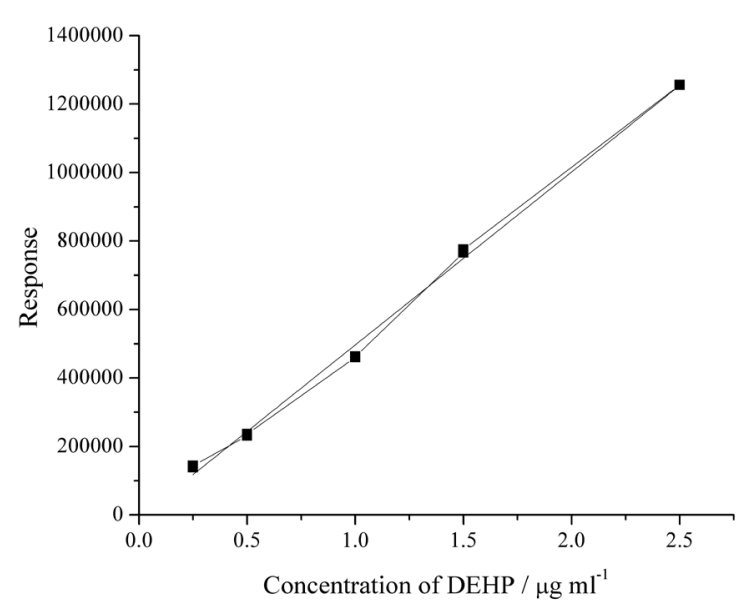

Figure 2. The calibration curve obtained for DEHP in the concentration range of $0.25-2.5 \mu \mathrm{g} \mathrm{mL}^{-1}$

Optimization of the extraction procedure

A few studies were performed in order to determine optimal conditions of the extraction procedure and are described below. The extraction procedure should include the solvent that is not miscible with alcoholic samples. Phthalates are highly soluble in $n$-hexane and this solvent is usually used for the extraction of phthalates. Bearing in mind that the extraction procedure requires an extraction solvent that is not miscible with the alcoholic sample, but n-hexane is miscible with ethanol, the presence of water in alcoholic samples causes the separation of the layers and easy phthalate migration from alcoholic samples to $n$-hexane layer. The separation between the two liquids was clear and visible. After spiking white spirits and the liquid-liquid extraction, a hexane layer was separated and the extracted phthalates were determined on GC-MS.

Tables 3 to 6 show the results of the recovery tests performed in triplicate.

By comparing the results obtained for non-evaporated 
alcohol samples (vodka and apple brandy) noted in Table 4 and 6 , it could be concluded that the recovery values for DMP were less for apple brandy alcoholic samples. The obtained results were expected since given the facts that apple brandy alcoholic samples contain more ethanol $(46 \% \mathrm{v} / \mathrm{v})$ from the sample of vodka $(40 \% \mathrm{v} / \mathrm{v})$ and the fact that DMP, as the most polar phthalate of other investigated phthalates, has the greatest tendency to dissolve in ethanol, and therefore a lower tendency migration into n-hexane. Recovery values for other investigated phthalates were similar for non-evaporated vodka and apple brandy, because they have a high tendency to migrate in $n$-hexane as a non-polar solvent than DMP. In the case of evaporated samples, ethanol was removed and the investigated phthalates were migrated from alcohol samples to $n$-hexane. The small differences between the recovery values for vodka and the apple spirit comes from different types of samples, or from other substituents in white spirits.
The impact of the re-extraction on the recovery of phthalate was analyzed. The data in Table 3 and 4 show that the re-extraction does not significantly affect the increase of the recovery of DBP, BBP, DEHP and DOP extraction in the case of both, evaporated and non-evaporated samples, but in the case of DMP, the increase of the recovery is significant. The recovery value for all phthalates except DMP was increased by $1.58-6.52$ $\%$ after the second extraction, $2.60-11.20 \%$ after the third extraction and $9.87-21.32 \%$ after the fourth extraction. For DMP, the recovery value was increased by $3.44-12.64 \%$ for evaporated vodka, and 14.47- 35.33 $\%$ for non-evaporated vodka. Bearing in mind that the increase in recoveries was low for the fourth phthalate compared to the time required for each re-extraction, as well as the cost of the analysis, further optimization of LLE was carried out with one extraction.

Table 3. Recoveries of phthalates extraction from evaporated vodka

\begin{tabular}{cccccc}
\hline \multirow{2}{*}{ Number of extractions } & \multicolumn{5}{c}{ Recovery (\%) (mean \pm SD) } \\
\cline { 2 - 6 } & DMP & DBP & BBP & DEHP & DOP \\
\hline 1 & $75.53 \pm 1.88$ & $43.10 \pm 1.55$ & $52.63 \pm 4.08$ & $45.76 \pm 2.17$ & $87.02 \pm 1.70$ \\
2 & $78.13 \pm 1.02$ & $44.20 \pm 0.96$ & $54.96 \pm 1.24$ & $48.21 \pm 3.79$ & $88.40 \pm 2.56$ \\
3 & $82.41 \pm 0.62$ & $45.31 \pm 0.64$ & $55.96 \pm 1.24$ & $52.21 \pm 3.79$ & $89.28 \pm 0.52$ \\
4 & $85.08 \pm 0.15$ & $52.29 \pm 1.12$ & $57.96 \pm 1.24$ & $55.21 \pm 3.79$ & $94.21 \pm 0.98$ \\
\hline
\end{tabular}

Table 4. Recoveries of phthalates extraction from non-evaporated vodka

\begin{tabular}{cccccc}
\hline \multirow{2}{*}{ Number of extractions } & DMP & DBP & BBP & DEHP & DOP \\
\hline 1 & $27.75 \pm 2.51$ & $54.90 \pm 1.56$ & $54.74 \pm 2.98$ & $57.33 \pm 2.12$ & $88.45 \pm 0.36$ \\
2 & $30.85 \pm 1.57$ & $56.56 \pm 0.62$ & $58.06 \pm 4.70$ & $59.03 \pm 5.66$ & $94.22 \pm 0.74$ \\
3 & $32.17 \pm 0.31$ & $58.61 \pm 0.56$ & $60.87 \pm 6.82$ & $60.53 \pm 2.12$ & $95.88 \pm 0.42$ \\
4 & $35.49 \pm 0.47$ & $60.32 \pm 0.63$ & $63.14 \pm 5.79$ & $65.01 \pm 2.83$ & $98.04 \pm 1.45$ \\
\hline
\end{tabular}

The obtained phthalates recoveries from evaporated alcohol samples and from non-evaporated alcohol samples are compared. Also, the effects of agitation and the agitation time are compared. The results are presented in Tables 5 and 6.

In the case of DMP, the best recovery was obtained by the extraction with hand shaking agitation of 5 minutes and removing a major part of ethanol from the apple white spirit. These results can be explained by the fact that DMP is the most polar phthalate from the group of investigated phthalates, and as such the most soluble in alcohol (ethanol). In case of non-evaporated samples, DMP remains were dissolved in it and did not migrate to non-polar hexane. When major part of ethanol was removed, the DMP easily migrates into $n$-hexane.

DOP shows the highest recovery of the phthalate extraction, because it is the most nonpolar and the largest molecule of the investigated phthalates and less dis- solved in polar alcohol than other investigated phthalates, and because of that, it has the greatest tendency to migrate in $n$-hexane. Also, alcohol evaporation does not have an impact on the recovery in the case of DOP, for the reasons above.

DBP, BBP and DEHP show similar solubility in water (Table 1), that is related with their similar structures, size and polarity, and for this reason they showed close recovery values of the phthalate extraction.

Regarding the influence of agitation time in the ultrasound bath, the results showed that time did not affect the migration of phthalates into $n$-hexane and recoveries of the phthalate extraction remain the same comparing to the first $10 \mathrm{~min}$ and after applicated times. 
Table 5. Recoveries of phthalates extraction from evaporated apple brandy

\begin{tabular}{|c|c|c|c|c|c|}
\hline \multirow[b]{2}{*}{ Type of agitation } & \multicolumn{5}{|c|}{ Recovery $(\%)($ mean \pm SD) } \\
\hline & DMP & DBP & BBP & DEHP & DOP \\
\hline $\begin{array}{c}10 \mathrm{~min} \\
\text { ultrasound }\end{array}$ & $76.89 \pm 2.01$ & $61.05 \pm 9.32$ & $69.78 \pm 0.56$ & $47.51 \pm 5.47$ & $68.93 \pm 3.57$ \\
\hline $\begin{array}{l}20 \mathrm{~min} \\
\text { ultrasound }\end{array}$ & $78.44 \pm 2.27$ & $49.28 \pm 12.66$ & $64.38 \pm 3.29$ & $37.67 \pm 8.55$ & $61.12 \pm 6.34$ \\
\hline $\begin{array}{c}30 \mathrm{~min} \\
\text { ultrasound }\end{array}$ & $78.37 \pm 1.08$ & $40.77 \pm 6.27$ & $57.13 \pm 8.53$ & $35.30 \pm 1.90$ & $62.75 \pm 8.41$ \\
\hline $\begin{array}{l}5 \text { min } \\
\text { handshaking }\end{array}$ & $110.78 \pm 6.16$ & $62.53 \pm 3.68$ & $74.81 \pm 2.35$ & $66.01 \pm 4.03$ & $105.38 \pm 4.18$ \\
\hline
\end{tabular}

Table 6. Recoveries of phthalates extraction from non-evaporated apple brandy

\begin{tabular}{cccccc}
\hline & \multicolumn{4}{c}{ Recovery (\%) (mean \pm SD) } \\
$\begin{array}{c}\text { Type of } \\
\text { agitation }\end{array}$ & DMP & DBP & BBP & DEHP & DOP \\
\hline $\begin{array}{c}10 \text { min } \\
\text { ultrasound } \\
20 \text { min }\end{array}$ & $21.97 \pm 0.80$ & $66.64 \pm 9.47$ & $66.23 \pm 10.63$ & $69.71 \pm 7.90$ & $104.67 \pm 0.47$ \\
$\begin{array}{c}\text { ultrasound } \\
30 \text { min }\end{array}$ & $21.39 \pm 0.13$ & $74.67 \pm 3.78$ & $61.05 \pm 2.52$ & $69.71 \pm 3.24$ & $109.96 \pm 2.98$ \\
$\begin{array}{c}\text { ultrasound } \\
5 \text { min }\end{array}$ & $21.61 \pm 0.84$ & $72.59 \pm 8.96$ & $57.72 \pm 5.02$ & $46.55 \pm 6.74$ & $67.19 \pm 7.06$ \\
handshaking & $27.31 \pm 0.22$ & $71.60 \pm 1.90$ & $66.38 \pm 1.68$ & $65.60 \pm 5.18$ & $90.95 \pm 4.19$ \\
\hline
\end{tabular}

Handshaking proved to be a better type of agitation for all phthalates compared to the effect of ultrasound, because during the ultrasound treatment emulsions emerge that in some way disable the complete immersion of phthalate into $n$-hexane.

All analyses were performed in triplicate and the determination was repeated twice. The laboratory contamination was monitored with blank samples obtained from alcohol samples without spiking of phthalates treated in the same way as the spiked alcohol samples.

\section{Conclusion}

In this study of phthalates determination in white spirits, the sample preparation method was optimized. The optimized method is fast, easy to perform and reliable. According to the obtained results, the best extraction method is selected: the use of $n$-hexane as the extraction solvent provided constant recovery values before and after the removal of the major part of ethanol, the extract agitation of the sample by hand shaking for five minutes and without re-extraction provided higher recoveries. The influence of removing the major part of ethanol from alcoholic samples is important for the determination of DMP, because that causes a significant increase of the recovery for DMP, from 27 to $110 \%$. In case of other investigated phthalates, removing the major part of ethanol from white spirits did not show this effect. The mean recovery values for spiking samples were $62-110 \%$ for the investigation of evaporated white spirits, and $27-90 \%$ for the investigation of non-evaporated white spirits.

\section{Acknowledgment}

This study was supported by the Ministry for Education, Science and Technological Development of the Republic of Serbia and was performed as part of Project TR 31060.

\section{References}

[1] D. Salazar-Beltrán, A. Hernández-Ramírez, L. HinojosaReyes, E. Ruiz-Ruiz, J.L. Guzmán-Mar, Phthalates in Beverages and Plastic Bottles: Sample Preparation and Determination, Food Analytical Methods, 11 (2018) 48-61.

[2] H.M. Koch, A.M. Calafat, Human Body burdens of chemicals used in plastic manufacture, Philosophical Transactions of The Royal Society B Biological Sciences, 364 (2009) 2063-2078.

[3] I.K. Mahood, H.M. Scott, R. Brown, N. Hallmark, M. Walker, R.M. Sharpe, In utero exposure to di(n-butyl) phthalate and testicular dysgenesis: Comparison of fetal and adult end points and their dose sensitivity, Environmental Health Perspectives, 115 (2007) 55-61.

[4] S.M. Duty, M.J. Silva, D.B. Barr, J.W. Brock, L. Ryan, Z. Chen, Phthalate Exposure and Human Semen Parameters, Epidemiology, 14 (2003) 269-277.

[5] B.A. Johnsson, J. Richthoff, L. Rylander, A. Giwercman, L. Hagmar, Urinary phthalate metabolites and biomarkers of reproductive function in young Swedish males, Epidemiology, 16 (2005) 487-493.

[6] K. Jurica, N. Ursulin-Trstenjak, D. Vukic Lusic, Z. Smit, 
Exposure to Phthalates and Their Presence in Alcoholic Beverages, Archives of Industrial Hygiene and Toxicology, 64 (2013) 317-325.

[7] Lv. Jianxia, L. Liang, H.-J. Huebschmann, Determination of Phthalates in Liquor Beverages by Single Quadrupole GC-MS, Thermo Scientific (Aplication Note 10339)

[8] Wisconsin Department of Natural Resources Laboratory Certification Program: Analytical Detection Limit Guidance \& Laboratory Guide for Determining Method Detection Limits (1996) (http://dnr.wi.gov/regulations/labcert/ documents/guidance/-lodguide.pdf)

[9] A. Fankhauser-Noti, K. Grob, Blank problems in trace analysis of diethylhexyl and dibutyl phthalate: Investigation of the sources, tips and tricks, Analytica Chimica Acta, 582(2) (2007) 353-360.

Izvod

\section{SIMULTANO ODREĐIVANJE PET FTALATA U BELIM RAKIJAMA KORIŠĆENJEM TEČNO-TEČNE EKSTRAKCIJE PRAĆENE GASNOM HROMATOGRAFIJOM}

Danica S. Bogdanović1 , Tatjana D. Anđelković1, Ivana S. Kostić1, Gordana M. Kocić2

(ORIGINALNI NAUČNI RAD) UDK 547.584:663.241:66.061:543.42

${ }^{1}$ Univerzitet u Nišu, Prirodno-matematički fakultet, Departman za hemiju, Niš, Srbija

2Univerzitet u Nišu, Medicinski fakultet, Niš, Srbija

Cilj ovog rada je razvijanje metode za određivanje pet ftalata u belim rakijama. Dimetil ftalat (DMP), di- $n$-butil ftalat (DBP), benzil butil ftalat (BBP), di-(2-etilheksil) ftalat (DEHP) i di-n-oktil ftalat (DOP) su ekstrahovani iz belih rakija optimizovanom tečno-tečnom ekstrakcijom. U cilju efikasnijeg određivanja ftalata, tečno-tečna ekstrakcija je optimizovana menjanjem sledećih parametara: broj ponavljanja ekstrakcije (1-4), uparavanje etanola iz belih rakija pre ekstrakcije, metoda agitacije i vreme ekstrakcije. Kvantifikacija je izvršena pomoću gasne hromatografije kuplovane sa masenom spektrometrijom sa di-n-butil-adipatom (DBA) kao internim standardom. Izabran je mod praćenja jednog jona (SIM), m/z 149 za DBP, BBP, DEHP i DOP i m/z 163 za DMP. Rezultati pokazuju da je najbolja metoda ekstrakcije sledeća: korišćenje $n$-heksana kao ekstrakcionog sredstva, ručno mućkanje 5 minuta bez ponavljanja ekstrakcije. Uparavanje etanola iz rakije utiče na značajno povećanje recoverija za DMP ali nema značajan efekat na povećanje recoverija za ostale ispitivane ftalate.
Ključne reči: ftalati, bele rakija, ekstrakcija, GC-MS analiza 